Research Article

\title{
Study of interaction of nifedipine with haloperidol on conditioned avoidance response and catalepsy in rats
}

\author{
Nitibhushansingh R. Chandel ${ }^{\mathrm{a}, *}$, Anant G. Phadke ${ }^{\mathrm{b}}$, Chhaya A. Goyal ${ }^{\mathrm{a}}$
}

\begin{abstract}
a Department of Pharmacology, SAIMS Medical College \& PG Institute, Indore, India,

${ }^{\mathrm{b}}$ Department of Pharmacology, JN Medical College, Sawangi

(Meghe), Wardha, India
\end{abstract}

Received: 1 October 2012

Revised: 30 October 2012

Accepted: 6 November 2012

\section{*Correspondence to:}

Dr. Nitibhushansingh R.

Chandel,

Email:

dr.nitinsingh1@gmail.com

\begin{abstract}
Background: To study the interaction of calcium channel blocker (Nifedipine) with Antipsychotic drug (Haloperidol) on Conditioned avoidance Response and catalepsy in Rats.

Methods: Every group consisted of 10 healthy albino rats of either sex. Different groups received Nifedipine $(5,10 \& 20 \mathrm{mg} / \mathrm{kg}$, i.p.), Haloperidol $\left(\mathrm{ED}_{50}-0.2 \mathrm{mg} / \mathrm{kg}\right.$ for CAR \& $0.4 \mathrm{mg} / \mathrm{kg}$ for catalepsy) alone and combined doses of both drugs. The Antipsychotic effect of drugs was measured by Conditioned avoidance response (CAR) using Cook's Pole climbing apparatus and Adverse drug effect (Extra pyramidal syndrome) was measured by Catalepsy.

Results: $5 \mathrm{mg} / \mathrm{kg}$ i.p. of Nifedipine inhibited CAR in $50 \%$ of Rats (compared to control, $p<0.001) .10 \mathrm{mg} / \mathrm{kg}$ i.p. of Nifedipine inhibited CAR in $60 \%$ of Rats $(p<0.001) \& 20 \mathrm{mg} / \mathrm{kg}$ i.p. inhibited CAR in $70 \%$ of Rats $(p<0.001)$. When Nifedipine $\left(5 \mathrm{mg} / \mathrm{kg}\right.$ i.p) was combined with Haloperidol $\mathrm{ED}_{50}-0.2 \mathrm{mg} / \mathrm{kg}$ the CAR was inhibited in $70 \%$ of the rats $(p<0.01)$ and after combining Nifedipine $(10 \mathrm{mg} / \mathrm{kg})$ with Haloperidol $\mathrm{ED}_{50}-0.2 \mathrm{mg} / \mathrm{kg}$ the CAR was inhibited in $80 \%$ Rats $(p<0.001)$. Nifedipine at the dose of $5 \mathrm{mg} / \mathrm{kg}$ and $10 \mathrm{mg} / \mathrm{kg}$ (i.p.) did not induce catalepsy in the rats at any testing time interval. At $20 \mathrm{mg} / \mathrm{kg}$ i.p., it produced catalepsy in 2 rats at half hour and in 4 rats at 1 hour and 2 hour testing interval each $(p<0.01)$. In the dose of 5,10 and $20 \mathrm{mg} / \mathrm{kg}$, pretreatment with Nifedipine significantly increased Haloperidol induced cataleptic scores at all testing intervals $(p<0.05)$.
\end{abstract}

Conclusions: Nifedipine blocked CAR. Its higher doses induced catalepsy and it is synergistic with haloperidol in blockade of CAR and catalepsy.

Keywords: Nifedipine, Haloperidol, Conditioned avoidance response (CAR), Catalepsy

\section{INTRODUCTION}

Schizophrenia is a devastating mental illness that affects $1 \%$ of the world Population. ${ }^{1}$ The Dopamine Hypothesis was put forth in the mid- $20^{\text {th }}$ century following the discovery of antipsychotic drugs. ${ }^{2}$ The antipsychotic drugs affect the metabolism of dopamine. ${ }^{3}$ The Pharmacological action of Antipsychotic drugs is directly linked to blockade of the dopamine D2 receptor. ${ }^{4,5}$ Too much dopamine in the basal ganglia is linked to Psychosis. ${ }^{6}$ The cognitive deficits is linked to too little dopamine in prefrontal cortex. ${ }^{7-9}$

Neurotransmitter release typically is triggered by a rise in intracellular $\mathrm{Ca}^{2+}$ concentration $\left[\mathrm{Ca}^{2+}\right]$, primarily from
$\mathrm{Ca}^{2+}$ influx through voltage- gated $\mathrm{Ca}^{2+}$ channels. ${ }^{10}$ Multiple calcium channels play a role in neurotransmitter release in the central nervous system. ${ }^{11} \mathrm{~K}^{+}$evoked dopamine release appears to involve both L-and N-type VSCC in striatum. ${ }^{12}$

Some studies reveal that Nifedipine suppresses selfinjurious behavior in four unrelated animal models. ${ }^{13}$ In animal experiments for Antipsychotic activity, it is found that Nifedipine $(5,10,20, \mathrm{mg} / \mathrm{kg}$ i.p. $)$ inhibited methamphetamine induced stereotypy (animal model of psychosis) in Albino rats and the effect of pretreatment with Nifedipine $(5,10,20 \mathrm{mg} / \mathrm{kg}$ i.p) on haloperidol induced catalepsy, showed significantly increased cataleptic scores and delayed onset of catalepsy. ${ }^{14}$ While 
other researchers stated that nifedipine, (5 \& $10 \mathrm{mg} / \mathrm{kg}$ ) attenuate haloperidol-induced catalepsy at high doses. ${ }^{15}$

There are individual reports of benefit of use of nifedipine, verapamil and flunarizine in management of Tourette's syndrome. ${ }^{16}$ Some authors have suggested that use of nifedipine in management of Tourette's syndrome may due to activity at dopamine receptors, either through direct blockade or by reducing depolarization of midbrain dopamine neurons. ${ }^{17}$

It has been found that in a double blind cross over trial that nifedipine may be effective in the treatment of tardive dyskinesia in patients of schizophrenia. ${ }^{18}$ Also, administration of nifedipine (30-60 mg/day) to eight schizophrenic patients with tardive dyskinesia in a single blind trial decreased Mean abnormal involuntary movement-scale scores. ${ }^{19}$

In view of the above facts, we decided to study the interaction of Nifedipine with haloperidol with the objectives to study antipsychotic activity and effect on catalepsy of Nifedipine alone and in combination with haloperidol.

\section{METHODS}

Conditioned avoidance response behavior (CAR) and catalepsy (CAT) are the standard preclinical tests used in the laboratory animals to predict the antipsychotic activity and motor side effects liability, respectively. ${ }^{20,21}$

The study was carried out after approval from Institutional Animal Ethical committee. Following Materials and Methods were used.

Healthy albino rats of either sex weighing between 100 to $200 \mathrm{gm}$ and maintained in identical conditions were selected. They were housed in colony cages with free access to food and water except just before and during experimentation. All the experiments were performed at room temperature in noiseless, well illuminated room at JNMC, Sawangi (Meghe), Wardha. The drugs used were Nifedipine powder (Cipla ltd.) in the doses of 5, 10, 20 $\mathrm{mg} / \mathrm{kg}$ given i.p. and Haloperidol (inj. Serenace, Sigma labs, Mumbai) in the dose of $1 \mathrm{mg} / \mathrm{kg}$. Nifedipine was dissolved in propylene glycol. The solutions were freshly prepared just before the experiments and concentrations were so adjusted that the volume of injection will be 0.1 $\mathrm{ml}$ per $100 \mathrm{gm}$ of body weight. All the drugs were injected intraperitoneally.

Conditioned avoidance response was studied in rats by using Cook's pole climbing apparatus ${ }^{22}$, manufactured by Techno, Lucknow.

Animals were conditioned to the sound of buzzer (30 seconds). This was followed by electroshock ( 80 volts, 5 pulses/sec). To avoid shock or punishment, animals learned to climb the pole at the sound of buzzer only. The effect of conditioned avoidance response was expressed as percentage of animals, which failed to climb the pole within $30 \mathrm{sec}$ in response to, subsequently delivered electric foot shocks.

Two different kinds of studies were conducted. In the first study, the effects of Nifedipine on CAR were observed. The first group received $1 \mathrm{ml} / \mathrm{kg}$ of Propylene glycol and served as control. To other group Nifedipine in the doses of $5 \mathrm{mg} / \mathrm{kg}, 10 \mathrm{mg} / \mathrm{kg}$, and $20 \mathrm{mg} / \mathrm{kg}$ were given. The CAR was performed at 1 hour after giving the drugs or Propylene glycol. Number of animals, which showed positive and negative responses in each group, was observed and the data recorded.

In the Second study, the effect of Nifedipine and $\mathrm{ED}_{50}$ dose of Haloperidol on CAR was observed. For this, the ED 50 dose of haloperidol was given after $60 \mathrm{~min}$ to one group of animals pretreated with Propylene glycol (1 $\mathrm{ml} / \mathrm{kg}$ ). This formed the control group for this study and observations were compared with this group. Nifedipine in the doses of $5 \mathrm{mg} / \mathrm{kg}, 10 \mathrm{mg} / \mathrm{kg}$, and $20 \mathrm{mg} / \mathrm{kg}$ was given to other group. After 1 hour, the $\mathrm{ED}_{50}$ dose of haloperidol was given to these pretreated groups. The CAR was performed after 1 hour following haloperidol. Number of Animals, which showed positive and negative responses in each group, were observed and recorded.

For testing catalepsy in animals two different types of studies were conducted. In the first study, the effect of Nifedipine alone on catalepsy was observed. Rats were tested for catalepsy by gently placing both the front limbs of the rat over an $8 \mathrm{~cm}$ high wooden block, placed horizontally above the tabletop and measuring the time that the animal maintained the imposed posture. ${ }^{20}$

Animals maintaining the imposed posture for more than $10 \mathrm{sec}$ were considered cataleptic. Scoring was done by Costall and Naylor methods. ${ }^{23}$ The first group received 1 $\mathrm{ml} / \mathrm{kg}$ body weight of Propylene glycol and served as control. To the other group Nifedipine in the dose of 5 $\mathrm{mg} / \mathrm{kg}, \quad 10 \mathrm{mg} / \mathrm{kg}$ and $20 \mathrm{mg} / \mathrm{kg}$ was given intraperitoneally. Animals were tested for catalepsy at 30 minutes, 60 minutes and 90 minutes after administration of Nifedipine and Propylene glycol.

In the second study, the effects of Nifedipine on haloperidol- induced catalepsy was observed. The control group received $1 \mathrm{ml} / \mathrm{kg}$ body weight of propylene glycol i.p $60 \mathrm{~min}$ before receiving $\mathrm{ED}_{50}$ dose $(0.4 \mathrm{mg} / \mathrm{kg})$ of haloperidol. To the other group, Nifedipine in three different doses of 5,10 and $20 \mathrm{mg} / \mathrm{kg}$ was given intraperitoneally $60 \mathrm{~min}$ before receiving $\mathrm{ED}_{50}$ dose $(0.4 \mathrm{mg} / \mathrm{kg})$ of haloperidol. The catalepsy was recorded at $30 \mathrm{~min}, 60 \mathrm{~min}$, and 120 minutes (cut off time) after haloperidol treatment. The duration of catalepsy of each rat in a group, at the respective testing time interval, was taken to compute the mean value of the group for that particular timing. 


\section{Statistical analysis}

Statistical analysis was done using Chi-square test for CAR. P $<0.05$ was considered to be significant. For haloperidol induced catalepsy, the results were analyzed by student's unpaired ' $\mathrm{t}$ ' test with differences considered significant at $\mathrm{P}<0.05$.

\section{RESULTS}

\section{[A] Conditioned Avoidance Response (CAR)}

\section{Study 1: Effect of nifedipine on CAR}

Nifedipine produced dose dependent suppression of CAR. In the dose of $5 \mathrm{mg} / \mathrm{kg}$ i.p., five rats out of ten climbed the pole on presentation of buzzer and 5 rats out of ten failed to climb the pole on buzzer. This means that in $50 \%$ of rats CAR was suppressed. But these rats climbed the pole after giving shock. i.e., the unconditioned response was not affected. This result is statistically significant $(p<0.001)$ (\% avoidances).

In the dose of $10 \mathrm{mg} / \mathrm{kg}$ i.p., four rats out of ten climbed the pole on buzzer and 6 rats out of ten failed to climb the pole on buzzer. This means that in $60 \%$ of rats CAR was suppressed (\% avoidances). However, these rats climbed the pole after shock. So the unconditioned response was not affected. This is statistically significant result $(p<0.001)$.

When Nifedipine was given in the dose of $20 \mathrm{mg} / \mathrm{kg}$ i.p, three rats out of ten climbed the pole on presentation of buzzer. 7 rats out of ten did not climb the pole on buzzer. This means that in $70 \%$ of animals CAR was suppressed (blocked). The unconditioned response was not affected. This result is also highly statistically significant $(p<0.001)$. Results are shown in Table 1.

Table 1: Effect of nifedipine on conditioned avoidance response in rats.

Positive response $=$ climbed the pole; Negative response $=$ did not climb the pole.

\begin{tabular}{|c|c|c|c|c|}
\hline Drugs and Dose (mg/kg) & $\begin{array}{c}\text { Positive response } \\
\text { (climbed on Buzzer) }\end{array}$ & $\begin{array}{c}\text { Negative Response (did } \\
\text { not climb on buzzer), } \\
\text { CAR Blocked }\end{array}$ & \% Climbing & $\begin{array}{c}\text { \% avoidance } \\
\text { (CAR } \\
\text { blockade) }\end{array}$ \\
\hline Propylene glycol & 10 & 0 & 100 & 0 \\
\hline Nifedipine 5 & 5 & 5 & 50 & $50^{* * *}$ \\
\hline NIfedipine10 & 4 & 6 & 40 & $60^{* * *}$ \\
\hline Nifedipine 20 & 3 & 7 & 30 & $70^{* * *}$ \\
\hline
\end{tabular}

$* * * \mathrm{p}<0.001$ as compared to propylene glycol treated control group by chi-square test $(n=10)$.

Table 2: Effects of nifedipine and haloperidol on conditioned avoidance response in rats.

\begin{tabular}{|c|c|c|c|c|}
\hline Drugs and doses & $\begin{array}{c}\text { Positive } \\
\text { response } \\
\text { (climbed on } \\
\text { Buzzer) }\end{array}$ & $\begin{array}{c}\text { Negative Response (did } \\
\text { not climb on buzzer), } \\
\text { CAR Blocked }\end{array}$ & \% Climbing & $\begin{array}{c}\text { \% avoidance (CAR } \\
\text { blockade) }\end{array}$ \\
\hline $\begin{array}{c}\text { Propylene Glycol }(1 \\
\mathrm{ml} / \mathrm{kg})+\end{array}$ & 5 & 5 & 50 & 50 \\
Haloperidol $0.2 \mathrm{mg} / \mathrm{kg})$ & 3 & 7 & 20 & $70^{* *}$ \\
\hline $\begin{array}{c}\text { Nifedipine }(5 \mathrm{mg} / \mathrm{kg})+ \\
\text { Haloperidol }(0.2 \mathrm{mg} / \mathrm{kg})\end{array}$ & 2 & 8 & 10 & $80^{* * * *}$ \\
\hline $\begin{array}{c}\text { Nifedipine }(10 \mathrm{mg} / \mathrm{kg})+ \\
\text { Haloperidol }(0.2 \mathrm{mg} / \mathrm{kg})\end{array}$ & & & \\
\hline
\end{tabular}

${ }^{* *} \mathrm{P}<0.01 ; * * * \mathrm{P}<0.001$ as compared to Propylene Glycol pretreated haloperidol group. 
Study 2: Effect of combining nifedipine and haloperidol $\left(E D_{50}\right.$ dose) on CAR

Blockade of CAR was dose dependent when Nifedipine was combined with $\mathrm{ED}_{50}$ dose of haloperidol. In the dose of $5 \mathrm{mg} / \mathrm{kg}$ i.p, $30 \%$ rats were able to climb the pole on presentation of buzzer and $70 \%$ of the rats failed to climb the pole on hearing the buzzer i.e., CAR was inhibited in $70 \%$ of the rats. However, the rats climbed the pole on presentation of shock i.e., the unconditioned response was not affected. This result is statistically significant $(p<0.01)$.
With $10 \mathrm{mg} / \mathrm{kg}$ i.p dose of Nifedipine and $0.2 \mathrm{mg} / \mathrm{kg}$ dose of haloperidol, $20 \%$ of rats were able to climb the pole on buzzer $80 \%$ of rats failed to climb the pole on buzzer. This means that $80 \%$ CAR was suppressed. However the rats climbed the pole on shock i.e., the unconditioned avoidance response was not affected. This result is highly significant statistically $(p<0.001)$. The results are shown in Table 2.

Table 3: Effect of nifedipine alone on catalepsy in rats.

\begin{tabular}{|c|c|c|c|c|c|c|}
\hline $\begin{array}{c}\text { Drugs and } \\
\text { Doses } \\
(\mathbf{m g} / \mathbf{k g})\end{array}$ & $\begin{array}{c}\text { 30 minutes } \\
\text { (duration in } \\
\text { seconds) } \\
\text { Mean } \pm \text { S.E.M }\end{array}$ & $\begin{array}{c}\text { (Scores) } \\
\text { Mean } \pm \\
\text { S.E.M }\end{array}$ & $\begin{array}{c}\text { 60 minutes } \\
\text { (duration in } \\
\text { seconds) } \\
\text { Mean } \pm \text { S.E.M }\end{array}$ & $\begin{array}{c}\text { (Scores) } \\
\text { Mean } \pm \\
\text { S.E.M }\end{array}$ & $\begin{array}{c}\text { 120 min } \\
\text { (duration in } \\
\text { seconds) } \\
\text { Mean } \pm \text { S.E.M }\end{array}$ & $\begin{array}{c}\text { Mean } \pm \\
\text { S.E.M }\end{array}$ \\
\hline $\begin{array}{c}\text { Propylene glycol } \\
\text { (control) } 1 \mathrm{ml} / \mathrm{kg}\end{array}$ & $3.0 \pm 0.20$ & 0 & $3.1 \pm 0.30$ & 0 & $3.2 \pm 0.30$ & 0 \\
\hline Nifedipine (5) & $3.1 \pm 0.15$ & 0 & $3.2 \pm 0.15$ & 0 & $3.4 \pm 0.18$ & 0 \\
\hline Nifedipine (10) & $3.2 \pm 0.24$ & 0 & $3.2 \pm 0.28$ & 0 & $3.4 \pm 0.27$ & 0 \\
\hline Nifedipine (20) & $29.3 \pm 13.87 * * *$ & $0.6 \pm 0.42^{* *}$ & $37.7 \pm .15 .37 * * *$ & $1.3 \pm 0.55^{* *}$ & $30.4 \pm 11.35^{* * *}$ & $0.8 \pm 0.43 * *$ \\
\hline
\end{tabular}

** $p<0.01$ as compared to propylene glycol treated control group by students unpaired ' $\mathrm{t}$ ' test $(n=10)$.

$* * * p<0.001$ as compared to propylene glycol treated control group by student's unpaired ' $\mathrm{t}$ ' test $(n=10)$.

Table 4: Effect of nifedipine on haloperidol induced catalepsy in rats.

\begin{tabular}{|c|c|c|c|c|c|c|}
\hline $\begin{array}{c}\text { Drugs and } \\
\text { doses(mg/kg) }\end{array}$ & $\begin{array}{c}30 \text { minutes } \\
\text { (duration in } \\
\text { seconds) } \\
\text { Mean } \pm \text { S.E.M }\end{array}$ & $\begin{array}{c}30 \text { minutes } \\
\text { (Scores) } \\
\text { Mean } \pm \text { S.E.M }\end{array}$ & $\begin{array}{c}60 \text { minutes } \\
\text { (duration in } \\
\text { seconds) } \\
\text { Mean } \pm \text { S.E.M }\end{array}$ & $\begin{array}{c}60 \text { minutes } \\
\text { (Scores) } \\
\text { Mean } \pm \text { S.E.M }\end{array}$ & $\begin{array}{l}120 \text { minutes } \\
\text { (duration in } \\
\text { seconds) } \\
\text { Mean } \pm \text { S.E.M }\end{array}$ & $\begin{array}{l}120 \text { minutes } \\
\text { (Scores) } \\
\text { Mean } \pm \text { S.E.M }\end{array}$ \\
\hline $\begin{array}{c}\text { Propylene } \\
\text { glycol } \\
(1 \mathrm{ml} / \mathrm{kg}) \\
\text { (control) }\end{array}$ & $3.0 \pm 0.20$ & 0 & $3.1 \pm 0.30$ & 0 & $3.2 \pm 0.30$ & 0 \\
\hline $\begin{array}{c}\text { Haloperidol } \\
(0.4)\end{array}$ & $42.5 \pm 16.44$ & $1.4 \pm 0.63$ & $48.8 \pm 14.91$ & $1.7 \pm 0.54$ & $59.9 \pm 14.59$ & $2.2 \pm 0.55$ \\
\hline Nifedipine (5) & $3.1 \pm 0.15$ & 0 & $3.2 \pm 0.15$ & 0 & $3.4 \pm 0.18$ & 0 \\
\hline $\begin{array}{c}\text { Nifedipine (5)+ } \\
\text { Haloperidol } \\
(0.4)\end{array}$ & $72.90 \pm 16.13^{*}$ & $2.4 \pm .28 *$ & $78.80 \pm 15.95^{*}$ & $2.8 \pm 0.35^{*}$ & $96.4 \pm 18.00 *$ & $3.1 \pm 0.40 *$ \\
\hline Nifedipine(10) & $3.2 \pm 0.24$ & 0 & $3.2 \pm 0.28$ & 0 & $3.4 \pm 0.27$ & 0 \\
\hline $\begin{array}{c}\text { Nifedipine } \\
(10)+ \\
\text { Haloperidol } \\
(0.4)\end{array}$ & $77.20 \pm 15.65^{*}$ & $2.5 \pm 0.25^{*}$ & $80.30 \pm 16.91 *$ & $3.0 \pm 0.15 *$ & $100.90 \pm 18.90 *$ & $3.5 \pm 0.35^{*}$ \\
\hline Nifedipine (20) & $29.3 \pm 13.87 * * *$ & $0.6 \pm 0.42 * *$ & $37.7 \pm 15.37 * * *$ & $1.37 \pm 0.55 * *$ & $30.4 \pm 11.35 * * *$ & $0.8 \pm 0.43 * *$ \\
\hline $\begin{array}{c}\text { Nifedipine } \\
(20)+ \\
\text { Haloperidol } \\
(0.4)\end{array}$ & $80.50 \pm 16.31 *$ & $3.6 \pm 0.20 *$ & $83.30 \pm 16.91 *$ & $3.1 \pm 0.25 *$ & $103.30 \pm 18.91 *$ & $3.6 \pm 0.20 *$ \\
\hline
\end{tabular}

$* p<0.05$ as compared with haloperidol treated group by student's unpaired ' $\mathrm{t}$ ' test $(n=10), * * p<0.05$ as compared with propylene glycol treated group by student's unpaired ' $\mathrm{t}$ ' test $(n=10),{ }^{* * *} p<0.001$ as compared with propylene glycol treated group by student's unpaired ' $t$ ' test $(n=10)$. 


\section{[B] Catalepsy}

\section{Study 1: Effect of nifedipine alone on catalepsy}

Nifedipine at the dose of $5 \mathrm{mg} / \mathrm{kg}$ and $10 \mathrm{mg} / \mathrm{kg}$ (i.p.) did not induce catalepsy in the rats at any testing time interval. At $20 \mathrm{mg} / \mathrm{kg}$ i.p., it produced catalepsy in 2 rats at half hour and in 4 rats at 1 hour and 2 hour testing interval each $(p<0.01)$.

The results are statistically significant $(p<0.001)$ at each time interval (for duration of catalepsy in seconds) and for the scores $(p<0.01)$. The results are expressed in duration of catalepsy (seconds) and scores (scoring is done by Costall Naylor method). The results are shown in Table 3.

\section{Study 2: Effect of nifedipine on haloperidol induced catalepsy}

In the dose of 5,10 and $20 \mathrm{mg} / \mathrm{kg}$, pretreatment with Nifedipine significantly increased cataleptic scores at all testing intervals $(p<0.05)$. The results are shown in Table 4.

\section{DISCUSSION}

The Pharmacological action of antipsychotic drugs is directly linked to blockade of the dopamine D2 receptor. ${ }^{4,5}$ Neurotransmitter release typically is triggered by a rise in intracellular $\mathrm{Ca}^{2+}$ concentration $\left[\mathrm{Ca}^{2+}\right]$, primarily from $\mathrm{Ca}^{2+}$ influx through voltage- gated $\mathrm{Ca}^{2+}$ channels. ${ }^{10}$ Multiple calcium channels play a role in neurotransmitter release in the central nervous system. ${ }^{11}$ So the role of calcium entry in neurotransmitter release is well known. Nifedipine has been found useful in management of Tourette's syndrome ${ }^{16}$, in treatment of tardive dyskinesia in patients of schizophrenia. ${ }^{18,19}$

In our study nifedipine $5,10,20 \mathrm{mg} / \mathrm{kg}$, significantly blocked conditioned avoidance response (Table 1). This finding is supportive to the findings found by Khanzode et al in another type of experimental model of psychosis. $^{14}$

It is also in agreement with possible usefulness of nifedipine in management of Tourette's syndrome ${ }^{16}$, in treatment of tardive dyskinesia in patients of Schizophrenia. ${ }^{18,19}$ Their effectiveness may be correlated to the activity at dopamine receptors, either through direct blockade or by reducing depolarization of midbrain dopamine neurons. ${ }^{17}$

Nifedipine 5, $10 \mathrm{mg} / \mathrm{kg}$ (Table 2) in a dose dependent manner, enhanced blockade of conditioned avoidance response by $\mathrm{ED}_{50}$ dose of haloperidol significantly. This may be due to synergistic action of haloperidol induced D2 receptor blockade and calcium channel blocker induced inhibition of dopamine release.

When used alone lower dose of nifedipine $5,10 \mathrm{mg} / \mathrm{kg}$ (Table 3) did not induce catalepsy while higher dose of nifedipine $20 \mathrm{mg} / \mathrm{kg}$ induced catalepsy. This may be correlated to the observation of Marie Lousie G, et al., ${ }^{24}$ that motor side effects require higher D2 receptor blockade.

High doses, $20 \mathrm{mg} / \mathrm{kg}$ of nifedipine may have inhibited dopamine release sufficiently to induce catalepsy. Pretreatment with nifedipine 10, $20 \mathrm{mg} / \mathrm{kg}$ (Table 4) significantly enhance catalepsy induced by $\mathrm{ED}_{50}$ dose of haloperidol. This is identical with observation of Khanzode et al., ${ }^{14}$ and differs from those of Biala et al., ${ }^{25}$ and Kozolovskii et al. ${ }^{15}$ This synergistic action may be due to haloperidol induced D2 blockade and calcium channel blocker induced inhibition of dopamine release.

\section{CONCLUSION}

To conclude haloperidol- a dopaminergic antagonist exerts antipsychotic action. Nifedipine inhibit dopamine release and exert synergistic action with haloperidol. Higher degree of dopaminergic blockade may produce catalepsy, which is enhanced by nifedipine, induced inhibition of dopamine release.

\section{REFERENCES}

1. Perez-Costas E, Melendez-Ferro M, Roberts RC. Basal ganglia pathology in Schizophrenia: Dopamine connections and Anomalies. J Neurochem 2010; 113:287-302.

2. Delay J, Deniker P, Harl JM. Therapeutic use in psychiatry of phenothiazine of central elective action0 (4560RP). Ann Med Psychol (Paris) 1952;110:112-7.

3. Carlsson A, Lindqvist M. Effect of Chlorpromazine or Haloperidol on formation of 3methoxytyramine and Normetanephrine in Mouse Brain. Acta Pharmacol Toxicol (Copenh). 1963;20:140-4.

4. Cresse I, Burt DR, Snyder SH. Dopamine receptor binding predicts clinical and Pharmacological potencies of antischizophrenic drugs. Science 1976;192:481-3.

5. Seeman $\mathrm{P}$, Lee $\mathrm{T}$, Chau-Wong $\mathrm{M}$, Wong $\mathrm{K}$. Antipsychotic drug doses and neuroleptics/dopamine receptors. Nature 1976;261:717-9.

6. Seeman P, Kapur S. Schizophrenia: more dopamine, more D2 receptors. Proc Natl Acad Sci U S A 2000;97:7673-5.

7. Carlsson A. The current status of the dopamine hypothesis of schizophrenia. Neuropsychopharmacology 1988;1:179-86.

8. Davis KL, Kahn RS, Ko G, Davidson M. Dopamine in schizophrenia: a review and reconceptulization. Am J Psychiatry 1991;148:1474-86.

9. Howes OD, Kapur S. The dopamine hypothesis of schizophrenia: version III-The final common Pathway. Schizophr Bull 2009;35:549-62.

10. Patel JC, Witkovsky P, Avshalumov MV, Rice ME. Mobilization of calcium from intracellular stores 
facilitates somatodendritic dopamine release. J Neurosci 2009;29:6568-79.

11. Olivera BM, Miljanich GP, Ramachandran J, Adams ME. Calcium channel diversity and neurotransmitter release: the omega-conotoxins and omega-agatoxins. Annu Rev Biochem 1994;63:82367.

12. Herdon H, Nahorski SR. Investigations of the roles of dihydropyridine and omega-conotoxin sensitive calcium channels in mediating depolarization evoked dopamine release from striatal slices. Naunyn schmiedebergs Arch Pharmacol 1989;340:36-40.

13. Blake BL, Muehlmann AM, Egami K, Breese GR, Devine DP, Jinnah HA. Nifedipine suppresses selfinjurious behaviors in animals. Dev Neurosci 2007;29:241-50.

14. Khanzode SD, Mahakalkar SM, Belorkar NR, Kharkar VT, Manekar MS. Effect of Pretreatment of some calcium channel blockers on catalepsy and stereotypic behavior in rats. Indian $\mathbf{J}$ Physiol Pharmacol 1996;40:159-62.

15. Kozlovskiǐ VL, Prakh'e IV, Kenunen OG. The influence of calcium channel blockers on the effects of haloperidol and phenamine in mice and rats. Eksp Klin Farmakol 1996;59:12-5.

16. Alessi NE, Walden M, Hsieh PS. Nifedipinehaloperidol combination in the treatment of Gilles de la Tourette's syndrome: a case study. J Clin Psychiatry 1989;50:103-4.

17. Marinelli M, Rudick CN, HuXT, White FJ. Excitability of dopamine neurons: modulation and physiological consequences. CNS Neurol Disord Drug Targets 2006;5:79-97.

18. Suddath RL, Straw GM, Freed WJ, Bigelow LB, Kirch DG, Wyatt RJ. A clinical trial of nifedipine in schizophrenia and tardive dyskinesia. Pharmacol Biochem Behav 1991;39:743-5.

19. Duncan E, Adler L, Angrist B, Rotrosen J. Nifedipine in treatment of Tardive dyskinesia. J Clin Psychopharmacol 1990;10:414-6.

20. Wadenburg ML. Serotonergic mechanisms in neuroleptic-induced catalepsy in the rat. Neurosci Biobehav Rev 1996;20:325-39.

21. Wadenburg ML, Hicks PB. The conditioned avoidance response test re-evaluated: is it a sensitive test for the detection of potentially atypical antipsychotics? Neurosci Biobehav Rev 1999;23:851-62.

22. Cook L, Weidley E. Behavioral effects of some psychopharmacological agents. Ann N Y Acad Sci 1957; 66:740-52.

23. Costall B, Naylor RJ. Mesolimbic involvement with behavioral effects indicating antipsychotic activity. Eur J Pharmacol 1974;27:46-58.

24. Wadenberg ML, Soliman A, VanderSpek SC, Kapur S. Dopamine $\mathrm{D}(2)$ receptor occupancy is a common mechanism underlying animal models of antipsychotics and their clinical effects. Neuropsychopharmacology 2001;25:633-41.

25. Biala G. Haloperidol induced catalepsy is influenced by calcium channel antagonists Acta Pol Pharm 2000;57:233-7.

doi: 10.5455/2319-2003.ijbcp003012

Cite this article as: Chandel NR, Phadke AG, Goyal

CA. Study of interaction of nifedipine with

haloperidol on conditioned avoidance response and

catalepsy in rats. Int J Basic Clin Pharmacol

2012;1:178-83. 